Article

\title{
Removal of Algae, and Taste and Odor Compounds by a Combination of Plant-Mineral Composite (PMC) Coagulant with UV-AOPs: Laboratory and Pilot Scale Studies
}

\author{
Yirga Weldu Abrha ${ }^{1,2}$, Homin Kye ${ }^{1}$, Minhwan Kwon ${ }^{1}$, Doorae Lee ${ }^{1}$, Kiho Kim ${ }^{1}$, Youmi Jung ${ }^{1}$, \\ Yongtae Ahn ${ }^{1}$ and Joon-Wun Kang ${ }^{1, *}$ \\ 1 Department of Environmental Engineering (YIEST), Yonsei University, 1 Yonseidae-gil, \\ Wonju, Gangwon-do 26493, Korea; yirga2016@yonsei.ac.kr (Y.W.A.); hominkye@yonsei.ac.kr (H.K.); \\ mkwon@trojanuv.com (M.K.); doorae@yonsei.ac.kr (D.L.); ksoo1211@yonsei.ac.kr (K.K.); \\ youmi116@gmail.com (Y.J.); walker34@naver.com (Y.A.) \\ 2 Department of Land Resource Management and Environmental Protection, Mekelle University, \\ P.O. Box 231, Mekelle, Ethiopia \\ * Correspondence: jwk@yonsei.ac.kr; Tel.: +82-33-760-2436; Fax: +82-33-760-2571
}

Received: 3 August 2018; Accepted: 27 August 2018; Published: 1 September 2018

Featured Application: The proposed combined plant-mineral composite coagulant with UV-AOPs can be applied to remove taste and odor compounds and its precursor (algae) in the drinking water system.

\begin{abstract}
The seasonal occurrence of algae blooms in surface waters remains a common problem, such as taste and odor (T\&Os), the risk of disinfection by-products (DBPs), and disturbance to water treatment systems. The coagulation efficiency of plant-mineral composite (PMC) coagulant followed by UV-based advanced oxidation processes (UV-AOPs; $\mathrm{UV} / \mathrm{H}_{2} \mathrm{O}_{2}$ and $\mathrm{UV} / \mathrm{Cl}_{2}$ ) was evaluated for removal of algae, turbidity, dissolved organic matters, and taste and odor compounds in lab-scale and pilot-scale tests. In the lab-scale test, coagulation process with $20 \mathrm{mg} / \mathrm{L}$ of PMC shows high removal efficiency of turbidity $(94 \%)$ and algae $(99 \%)$ and moderate removal efficiency of $U_{254}$ $(51 \%)$ and geosmin $(46 \%)$. The pilot test results also show good removal efficiency of turbidity $(64 \%)$, chlorophyll-a (96\%). After PMC coagulation process, the major water factors, which affected the performance of UV-AOPs (i.e., UV transmittance (85-94\%), and scavenging factor $\left(64,998-28,516 \mathrm{~s}^{-1}\right)$ ), were notably improved, and further degradation of geosmin and 2-methylisoborneol (2-MIB) was achieved in both lab-and pilot-scale tests of the UV-AOPs. The $\mathrm{UV} / \mathrm{H}_{2} \mathrm{O}_{2}$ process shows higher removal efficiency of geosmin and 2-MIB than the $\mathrm{UV} / \mathrm{Cl}_{2}$ process because of the $\mathrm{pH}$ effect. The results confirmed that the PMC-based coagulation followed by $\mathrm{UV} / \mathrm{H}_{2} \mathrm{O}_{2}$ process could be an effective process for the removal of algae, geosmin, and 2-MIB.
\end{abstract}

Keywords: advanced oxidation process; algae; coagulation; geosmin; 2-MIB; plant-mineral composite coagulant

\section{Introduction}

Harmful algae bloom problems are becoming more serious with increasing frequency and quantity in the aquatic environment [1]. Especially in drinking water sources in Korea, the problem is significant because of the impact of the harmful algal on the water treatment performance [2]. An algal bloom event results in the release of geosmin, 2-methylisoborneol (2-MIB) and taste and odor (T\&O) 
compounds from the algal cells during and after bloom events. The toxic and/or odorous metabolites produced by these blooms impact the drinking water quality. Odors of organic compounds produced by algae are characterized as earthy and musty/camphorous. Odors of such compounds can be easily sensed by the human nose even at extremely low concentrations, e.g., concentrations as low as 4.0 and $8.5 \mathrm{ng} / \mathrm{L}$ for geosmin and 2-MIB, respectively [3].

Various mitigation methods for algae and T\&O problems have been examined, including coagulation, filtration, potassium permanganate, chlorine and ozone treatments [4-6]. Among those processes, the coagulation stage is recommended for removal of algae to ensure minimal impact on subsequent processes and prevent the release of the toxic or T\&O compounds from cell destruction [7]. However, some of the most commonly used coagulants (e.g., aluminum salts) have disadvantages, such as production of harmful sludge and residuals in the treated water, which can be harmful to human health $[8,9]$.

In practice, owing to the variability in water quality and low degradability of certain compounds, achieving the desired water quality by using a single conventional method for removal of algae, geosmin, and 2-MIB is difficult. Implementation of nontoxic and easy-to-use treatment methods to protect drinking water from algal-bloom-related problems is needed. Therefore, the water industry is exploring alternatives to replace Al-based coagulants and ways to strengthen methods that combine coagulation and advanced oxidation processes (AOPs). One effort that has been made in this context is the investigation of the use of a new coagulant that is based on a plant-mineral composite (PMC) for water treatment [10], which was selected to reduce the aluminum sludge and residuals and evaluated for treatment of algae and dissolved organic matters (DOMs) in a lab-scale batch system and a pilot-scale flowing system $\left(109 \mathrm{~m}^{3} / \mathrm{h}\right)$. The pilot facility was installed at a water intake station from Han-river in Korea. The PMC-based coagulant consists of mixtures of indigenous plant extracts (e.g., Camellia sinensis, Quercus acutissima, and Castanea crenata) and minerals (e.g., loess, quartz porphyry, and natural zeolite) [10]. In reservoir water treatment, PMC performance was found to be effective in removing chlorophyll-a (88-98\%), phytoplankton (84-92\%) and zooplankton [11]. Moreover, about $70 \%$ removal efficiency of turbidity and suspended solids was also reported in the reservoir water [11]. In the present study, the algae and its metabolite removal efficiencies in the drinking water system of PMC based coagulation process were evaluated. For the case that required higher removal efficiency of T\&O compounds, $\mathrm{UV}$ based $\mathrm{AOPs}$, i.e., $\mathrm{UV} / \mathrm{H}_{2} \mathrm{O}_{2}$ and $\mathrm{UV} / \mathrm{Cl}_{2}$ processes, were also evaluated as a following processes of the PMC coagulation process. The geosmin and 2-MIB removal efficiencies could be enhanced through several options like simultaneous application of various AOPs, achieving safety and subsequent suitability of the drinking water [12,13]. UV-based AOPs are well-established processes which have been implemented worldwide and have distinct benefits for simple installation and small footprint.

The aim of this study was (1) to evaluate the PMC for removal of algae, turbidity, dissolved organic matter and mechanism of coagulation; (2) to evaluate the combination process of PMC coagulation with UV-based AOPs to remove T\&O compounds.

\section{Materials and Methods}

\subsection{Reagents and Materials}

All reagents used were of analytical grade, unless mentioned otherwise. Geosmin $(>97 \%)$ and 2-MIB ( $>98 \%$ ) dissolved in methanol were purchased from Dalton Pharma Services (Toronto, ON, Canada) and diluted in deionized water for further use. Sulfuric acid (98.08\%) and hydrogen peroxide $\left(\mathrm{H}_{2} \mathrm{O}_{2} ; 30 \mathrm{wt} \%\right.$ solution) were purchased from Kanto Chemical Co., Inc. (Tokyo, Japan) and Sigma-Aldrich Korea (Seoul, Korea), respectively. $\mathrm{HCl}(30 \%)$ and sodium chloride (>99\%) were purchased from Duksan Chemical Co., Ltd. (Ansan, Korea). The PMC-based coagulant that consisted of silicate $(20 \%)$, barleystone $(20 \%)$, loess $(10 \%)$, kaolin $(3 \%)$, sericite $(3 \%)$, and zeolite $(4 \%)$ and extracts 
from chestnut $(6.5 \%)$, sawtooth oak $(6.5 \%)$, green tea plant $(6.5 \%)$, persimmon $(6.5 \%)$, ash tree $(6.5 \%)$, and pine (6.5\%) volume\% was from MCE Korea and K-water (Hongseong-gun, Korea).

\subsection{Experimental Procedure}

\subsubsection{Lab-Scale Experiment}

Raw water was collected at the pilot plant site (Han River, South Korea). The raw water was stored at $4{ }^{\circ} \mathrm{C}$ immediately after collection. The jar test experiment was conducted at 22 to $25{ }^{\circ} \mathrm{C}$.

Anabaena sp. (AG10279) was obtained from the Korean Type Culture Collection (KTCC). Anabaena sp. was cultured in a $250 \mathrm{~mL}$ Erlenmeyer flask with a BG-11 media and under culture conditions of a constant temperature of $25^{\circ} \mathrm{C}$, light exposure for $12 \mathrm{~h}\left(150 \mu \mathrm{mol} \cdot \mathrm{m}^{-2} \cdot \mathrm{s}^{-1}\right)$ and dark intervals for $12 \mathrm{~h}$ with a shaking speed of $150 \mathrm{rpm}$. To examine the algae removal efficiency of the PMC-based coagulant, a known amount of Anabaena sp. culture was mixed with raw water collected from the Han River. A water sample for lab-scale tests was prepared by injecting Anabaena sp., into the raw water collected from the influent of the pilot system. To ensure stable algae concentration, we monitored the optical density at $680 \mathrm{~nm}\left(\mathrm{OD}_{680}\right)$ of the test water using a spectrophotometer [14]. The $\mathrm{OD}_{680}$ of the sample solution was stable after $6 \mathrm{~h}$, and the initial concentration of chlorophyll-a was measured as $97.1 \mathrm{mg} / \mathrm{m}^{3}$. Other parameters of the tested water are listed in Table 1.

Table 1. Water quality parameters of raw water used in the lab-scale and pilot-scale tests.

\begin{tabular}{cccc}
\hline Parameters & Lab-Scale Test & First Pilot-Scale Test & Second Pilot-Scale Test \\
\hline Turbidity $(\mathrm{NTU})$ & 4.6 & 1.1 & 15.6 \\
$\mathrm{DOC}(\mathrm{mg} / \mathrm{L})$ & 3.4 & 0.9 & 0.8 \\
$\mathrm{UV}_{254}\left(\mathrm{~cm}^{-1}\right)$ & 0.034 & 0.015 & 0.027 \\
$\mathrm{pH}$ & 7.8 & 6.9 & 6.7 \\
chlorophyll-a $\left(\mathrm{mg} / \mathrm{m}^{3}\right)$ & 97.1 & 0.5 & 0.7 \\
Target chemicals & 134.6 ng/L geosmin & $100.0 \mathrm{ng} / \mathrm{L}$ geosmin & $100.0 \mathrm{ng} / \mathrm{L} \mathrm{geosmin}$ \\
& $159.0 \mathrm{ng} / \mathrm{L}$ 2-methylisoborneol (2-MIB) & $80.0 \mathrm{ng} / \mathrm{L}$ 2-MIB & $80.0 \mathrm{ng} / \mathrm{L}$ 2-MIB \\
\hline
\end{tabular}

The coagulation process was conducted using a programmable jar tester to determine the optimum dose of PMC for the removal of algae, turbidity, and organic matters from the incident water of the pilot system. The PMC was added to $1 \mathrm{~L}$ of raw water in a $1 \mathrm{~L}$ beaker. The addition of PMC was followed by rapid mixing at $140 \mathrm{rpm}$ for $1 \mathrm{~min}$, then slow mixing at $40 \mathrm{rpm}$ for $59 \mathrm{~min}$. These conditions were determined to simulate the pilot-system. After allowing the contents in the beaker to settle for $30 \mathrm{~min}$, samples for water quality measurements were collected from approximately $3 \mathrm{~cm}$ below the water surface. Varying PMC-based coagulant dose, with five levels $(0,5,10,20,40$, and $70 \mathrm{mg} / \mathrm{L})$ were evaluated for algal cells, turbidity, dissolved organic carbon (DOC), and $\mathrm{UV}_{254}$ removal. The zeta potentials of the coagulated samples with varying doses of coagulant were also measured.

The photodegradation experiments were carried out using a bench-scale quasi-collimated beam apparatus [15] equipped with two 11-W low-pressure lamps (Philips, Amsterdam, The Netherland), which primarily emit light at $253.7 \mathrm{~nm}$. A $50 \mathrm{~mL}$ geosmin and 2-MIB aliquot was placed in a Petri dish at a depth of about $0.786 \mathrm{~cm}$ [15-17]. The solution was stirred using a cross-shaped stirring bar with a diameter of $1 \mathrm{~cm}$ to ensure that it was homogenously exposed to UV light, and the solution is well mixed in the system. The UV irradiance $\left(\mathrm{mW} / \mathrm{cm}^{2}\right)$ was determined using the peroxide actinometry method with a calibrated radiometer equipped with a UV 254 detector (UVX Radiometer; UVP, Upland, CA, USA) at the height of the surface of the Petri dish $[15,17]$. The average incident irradiance across the surface of the solution was determined using a Petri factor and a reflection factor [15].

\subsubsection{Pilot-Scale Experiment}

Pilot-scale experiments were conducted in a water treatment plant (WTP) intake station during late spring (April and May) and summer (July), which takes raw water from Han-river in Korea. 
To examine the coagulation efficiency of PMC-based coagulant at pilot-scale $\left(109 \mathrm{~m}^{3} / \mathrm{h}\right)$, varying doses of the PMC-based coagulant $(0,10,20,30$, and $40 \mathrm{mg} / \mathrm{L})$ were evaluated for chlorophyll-a, turbidity, and $\mathrm{UV}_{254}$ removal. Online chlorophyll-a concentration measurement was carried out using a PLC automatic control system (Namyangju, Korea). The concentrations of chlorophyll-a in the raw water ranged from 2.3 to $156 \mathrm{mg} / \mathrm{m}^{3}$.

After the PMC-based coagulation process, the treated water was branched to conduct the UV AOPs experiments. The flow rate in UV system was around $1.8 \mathrm{~m}^{3} / \mathrm{hr}$, and geosmin, 2-MIB were spiked into the influent of the UV reactor. The UV reactor was a LPA15 system with one low-pressure amalgam lamp rated at $871.8 \mathrm{~mJ} / \mathrm{cm}^{2}$. The contaminant and oxidant (i.e., hydrogen peroxide and chlorine) stock solutions were injected into the UV influent pipe through separate injection ports. The effluent sampling port was sufficiently far downstream from the injection ports to ensure that the stream was well mixed before reaching the sampling port and that representative samples were collected. The schematic design of the combined treatment is shown in Figure 1.

\section{Combined treatment}

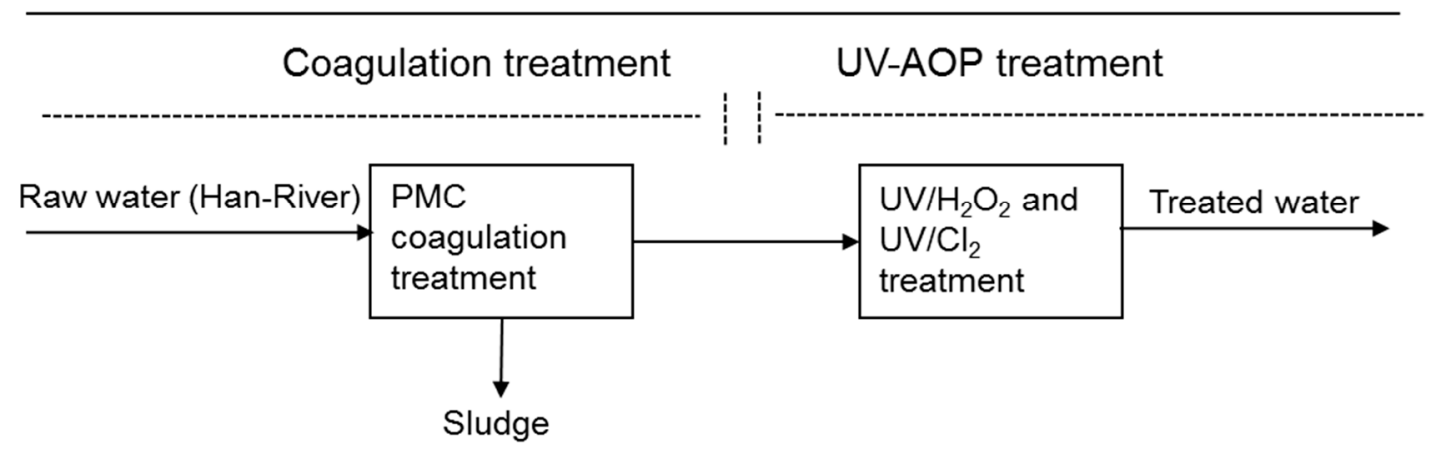

Figure 1. Schematic design of the combined treatment, plant-mineral composite (PMC) coagulation treatment followed by UV-based advanced oxidation processes (UV-AOP) treatment.

\subsection{Analysis}

Turbidity was measured using a Hach $2100 \mathrm{~N}$ Turbidimeter (Hach Company, Loveland, CO, USA). A total organic carbon (TOC) analyzer (Dong-il SHIMADZU Corp., Seoul, Korea) was used to measure the DOC of samples after filtration through a cellulose acetate membrane (pore size: $0.45 \mu \mathrm{m}$ ). A spectrophotometer (Cary 50 Probe, Varian Australia Pty, Ltd., Melbourne, Australia) was used to measure the $\mathrm{UV}_{254}$ of samples after filtration through a membrane (pore size: $0.45 \mu \mathrm{m}$ ). A pH meter (Thermo Fisher Scientific Inc., Singapore, Singapore), which was calibrated daily using standards of $\mathrm{pH}$ 4.0, 7.0, and 10.0, was used to measure the $\mathrm{pH}$ of the water samples. A microscope was used to count the algal cells. A zeta-potential \& particle size analyzer (Otsuka Electronics Co., Ltd., Osaka, Japan) was used to determine the zeta potential of the coagulant.

The concentrations of geosmin and 2-MIB were determined using a gas chromatograph equipped with a Polaris Q ion-trap mass spectrometer (Thermo Fisher Scientific, Waltham, MA, USA). Separation of different compounds was achieved using a J\&W CP-Sil 5 CB MS column (length: $30 \mathrm{~m}$; internal diameter: $0.25 \mathrm{~mm}$; film thickness: $0.25 \mu \mathrm{m}$; Agilent Technologies, Santa Clara, CA, USA). The GC oven temperature was held at $40^{\circ} \mathrm{C}$ for $2 \mathrm{~min}$, increased by $7{ }^{\circ} \mathrm{C} \mathrm{min}^{-1}$ to $200{ }^{\circ} \mathrm{C}$, which was held for

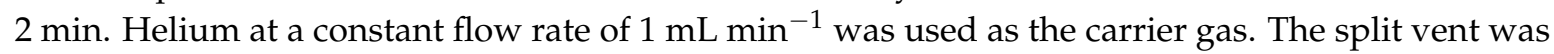
opened for $3 \mathrm{~min}$ after the injection. The electron impact ionization modes were as follows: ion source temperature of $230^{\circ} \mathrm{C}$; the transfer line temperature of $280{ }^{\circ} \mathrm{C}$; solvent delay time of $5 \mathrm{~min}$; electron energy of $70 \mathrm{eV}$. The full scan mass spectra were obtained at a mass-to-charge ratio scan ranging from 50 to $350 \mathrm{amu}$ to determine appropriate masses for selected ion monitoring [18].

A colorimetric method for the determination of peroxidase with $N, N$-diethyl-p-phenylenediamine (DPD) was used to determine the concentrations of $\mathrm{H}_{2} \mathrm{O}_{2}$ and chlorine using a DR/2500 spectrophotometer 
(Hach, Loveland, CO, USA) at $530 \mathrm{~nm}$. The spectrophotometer was calibrated using $10 \mathrm{~mL}$ of water sample as a blank. A $10 \mathrm{~mL}$ water sample pipetted into a sample cell. Then, one DPD free chlorine Powder Pillow was added and mixed well. After adding $25 \mu \mathrm{L}(1 \mathrm{~g} / \mathrm{L}$ peroxidase stock solution) of peroxidase reagent, the chlorine concentration measured in $\mathrm{mg} / \mathrm{L}$. For the $\mathrm{H}_{2} \mathrm{O}_{2}$, the chlorine result was divided by two [19-21].

\section{Results and Discussion}

\subsection{PMC for Algae and Organic Matters Removal, Lab-Scale}

Figure 2 shows the removal efficiency of algae and turbidity as a function of varied PMC-based coagulant dose from 0 to $70 \mathrm{mg} / \mathrm{L}$ at 22 to $25^{\circ} \mathrm{C}$. Overall, the degradation tendencies of algae and turbidity were similar. The removal efficiencies of both algae and turbidity tended to increase with increasing PMC dose up to $20 \mathrm{mg} / \mathrm{L}$, with further increase in the PMC dose decreasing the algae and turbidity removal efficiency. The highest removal of algae was found to be $98 \%$ at $20 \mathrm{mg} / \mathrm{L}$ PMC. For the case of turbidity, the removal efficiency was around $94 \%$ at $20 \mathrm{mg} / \mathrm{L} \mathrm{PMC}$, but it was decreased to $83.4 \%$ at $70 \mathrm{mg} / \mathrm{L}$ PMC. It was implied that particles repelled each other due to the strong electrostatic repulsion forces caused by adsorbed polycations, as reported earlier in [22]. The algae removal efficiencies achieved with the PMC were approximately 10 to $19 \%$ higher than those reported in previous work using Al-based [2].

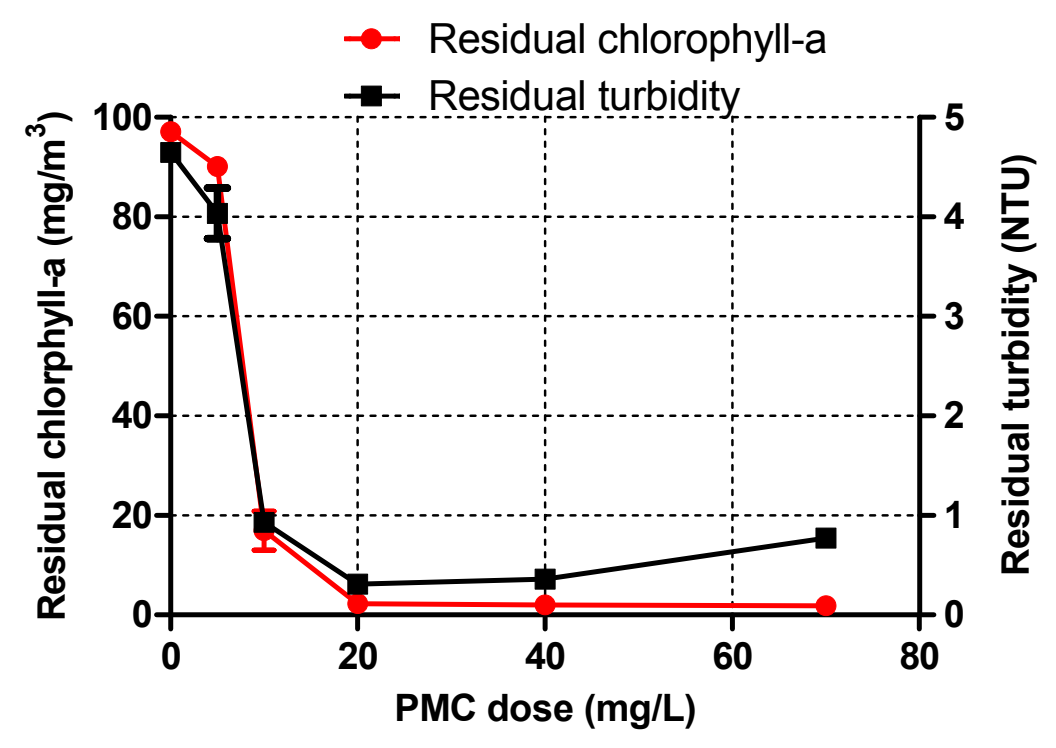

Figure 2. Concentration of chlorophyll-a and residual turbidity after removal with varying doses of the PMC-based coagulant $(0,5,10,20,40$, and $70 \mathrm{mg} / \mathrm{L})$.

Figure 3 shows the removal efficiency of $\mathrm{UV}_{254}$ and DOC as a function of initial dose of the PMC. $\mathrm{UV}_{254}$ and DOC are parameters for monitoring the dissolved organic matter (DOM) removal and controlling coagulant doses in water supply systems for the removal of TOC [23]. The initial $\mathrm{UV}_{254}$ and initial concentration of DOC were $0.034 \mathrm{~cm}^{-1}$ and $3.4 \mathrm{mg} / \mathrm{L}$, respectively.

In the coagulation process, the removal efficiency of both parameters, i.e., $\mathrm{UV}_{254}$ and DOC, increased with increasing PMC dose (Figure 3). At $20 \mathrm{mg} / \mathrm{L} \mathrm{PMC}$, the $\mathrm{UV}_{254}$ and DOC removals were found to be $51 \%$ and $14 \%$, respectively. The higher $\mathrm{UV}_{254}$ removal efficiencies than the DOC removal indicates that hydrophobic and large aromatic compounds were preferentially removed via the coagulation process [24]. Ghernaout et al. [25] also reported that small aliphatic compounds do not absorb UV light because they lack conjugated double bonds, and therefore are not detected through $\mathrm{UV}_{254}$ measurements. This finding is in agreement with those of previous studies [25-27]. 


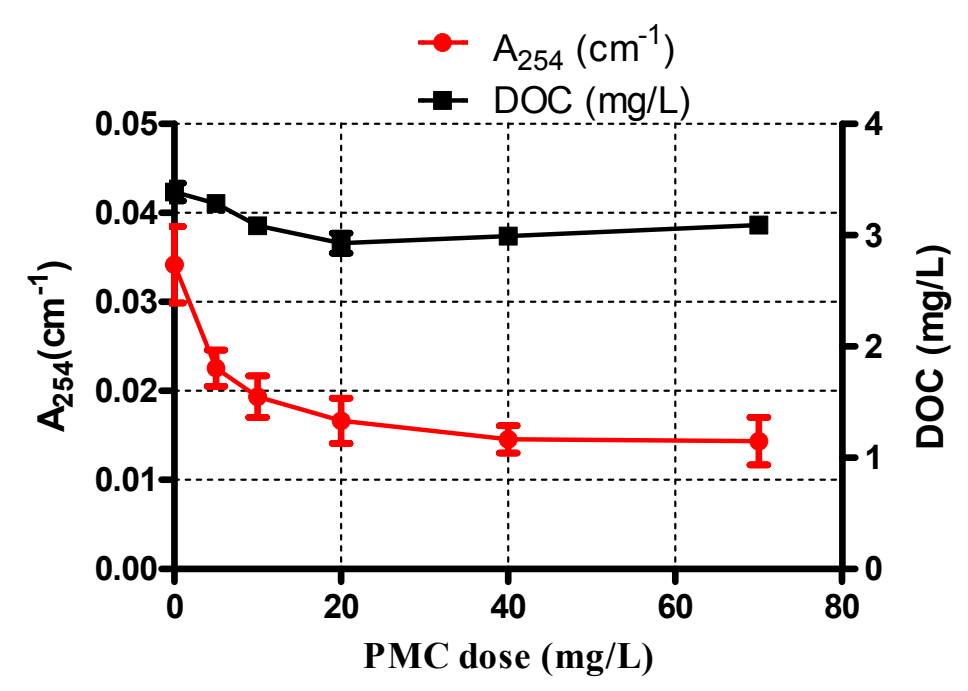

Figure 3. Removal of $\mathrm{UV}_{254}$ and dissolved organic carbon (DOC) at the laboratory-scale using varying doses of the PMC-based coagulant $(0,5,10,20,40$, and $70 \mathrm{mg} / \mathrm{L})$.

\subsection{Zeta Potential of PMC}

The zeta potential of the test water at varying PMC-based coagulant doses was determined to investigate the mechanism of turbidity and algae removal. With increasing PMC dose from 0 to $70 \mathrm{mg} / \mathrm{L}$, the zeta potential was increased from $-26.3 \mathrm{mV}$ to $+27.1 \mathrm{mV}$ (Figure 4). This could be explained by the highly positive charge of the PMC stock solution $(+44.86 \mathrm{mV})$. The isoelectric point was found to be around $20-40 \mathrm{mg} / \mathrm{L}$ PMC dose, which range is close to the optimum PMC dose for the algae and turbidity removal, i.e., $20 \mathrm{mg} / \mathrm{L}$ (Figure 4). This result indicates that the charge neutralization could be the major removal mechanism of algae and turbidity in coagulation process [28]. At the PMC dose higher than $20 \mathrm{mg} / \mathrm{L}$, the reversal of the solution charge from negative to positive could lead to restabilization of the particles. The particles could repel each other, owing to strong electrostatic repulsion forces caused by the adsorbed polycations [22]. Moreover, algae bio-colloids are known to carry negative surface charges at most $\mathrm{pH}$ levels [29]. Thus, the high algae removal efficiencies of the PMC can be attributed to the mechanisms of charge neutralization and mutual attraction between the negatively charged algae and the positively charged components of the PMC-based coagulant (i.e., zeolite, barley stone, and loess) [10].

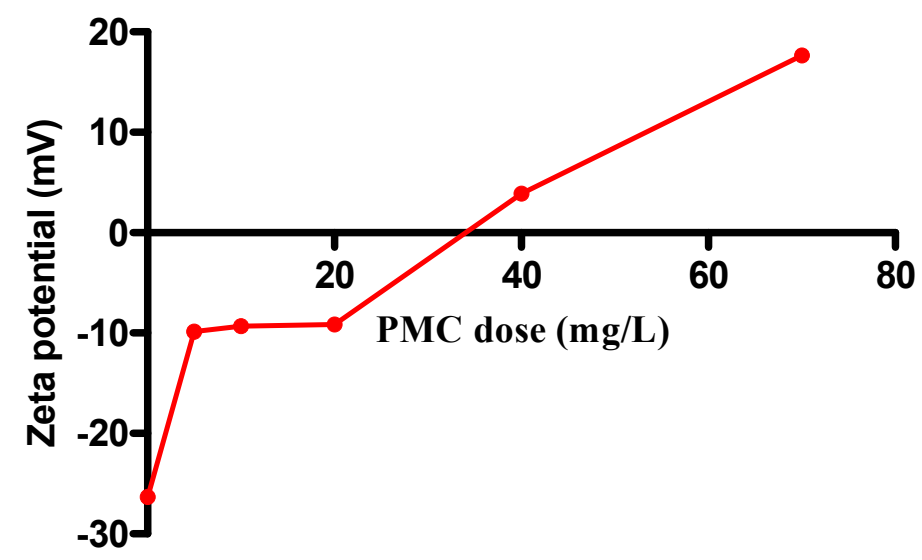

Figure 4. Effect of PMC-based coagulant dose (0, 5, 10, 20, 40, and $70 \mathrm{mg} / \mathrm{L})$ on Zeta potential. 


\section{3. $p H$ and Alkalinity}

The changes in solution $\mathrm{pH}$ and alkalinity after coagulation with various PMC-based coagulant doses are shown in Figure 5. The initial $\mathrm{pH}$ of the raw water was approximately 7.8. The jar test was conducted with varying doses of the PMC-based coagulant, and the effect of PMC dose on the $\mathrm{pH}$ of the test water was evaluated. It was observed that the test water $\mathrm{pH}$ decreased after addition of the PMC-based coagulant. Increasing the PMC dose decreased the $\mathrm{pH}$ and alkalinity of the test water. The $\mathrm{pH}$ decreased to approximately 7.0 at the optimum PMC-based coagulant dose, which indicates that the alkalinity consumption of the PMC coagulant is less than that of alum-based chemical coagulants [30,31].

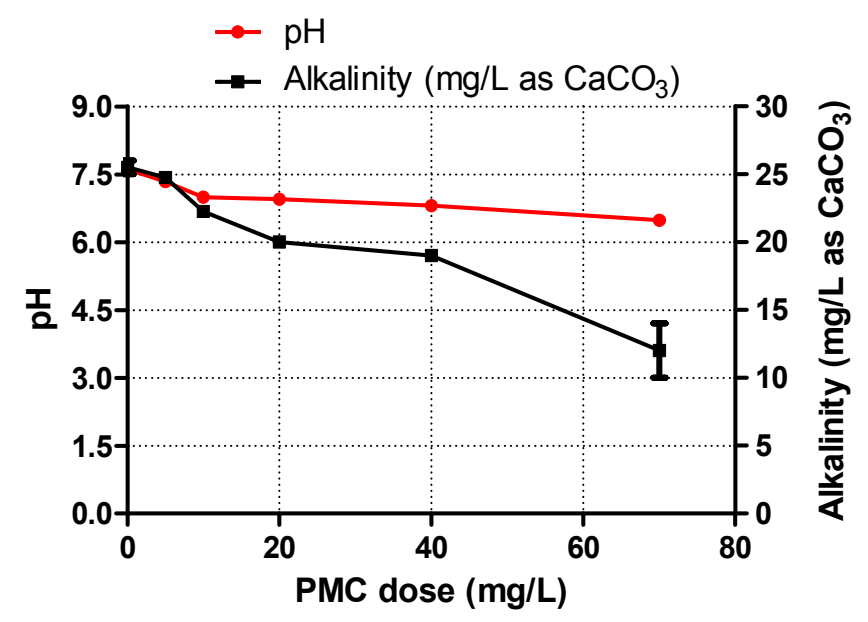

Figure 5. Effect of coagulant dose on $\mathrm{pH}$ and alkalinity with varying doses of the PMC coagulant $(0,5$, $10,20,40$, and $70 \mathrm{mg} / \mathrm{L})$.

\subsection{PMC for Geosmin and 2-MIB Removal}

The geosmin and 2-MIB removal efficiencies of the different PMC doses were investigated. In the coagulation process, PMC-based coagulant was injected up to $70 \mathrm{mg} / \mathrm{L}$. The removal efficiency of geosmin and 2-MIB increased with increasing the PMC dose in both processes (Figure 6). The removal efficiency of geosmin and 2-MIB at $20 \mathrm{mg} / \mathrm{L}$ of PMC was approximately $46 \%$ and $37 \%$, respectively. The removal efficiencies were higher for geosmin than for 2-MIB. This was attributed to the flatter structure and solubility of geosmin than 2-MIB [1].

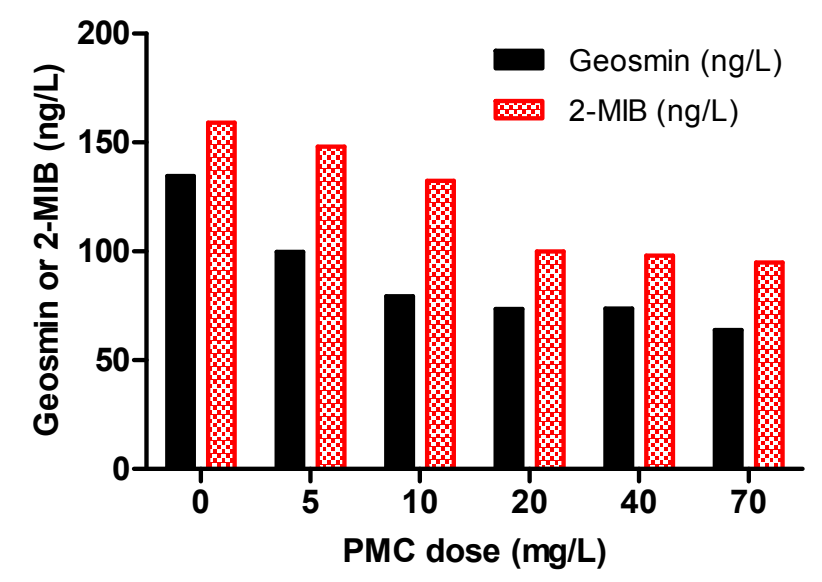

Figure 6. Trends in geosmin and 2-methylisoborneol (2-MIB) removal by PMC processes at the lab-scale (initial geosmin concentration $=134.58 \mathrm{ng} / \mathrm{L}$; initial 2-MIB concentration $=159.02 \mathrm{ng} / \mathrm{L} ;$ PMC dose: 0 , 5, 10, 20, 40 and $70 \mathrm{mg} / \mathrm{L})$. 
From the results in Figure 6, it was found that PMC coagulation process could remove some geosmin and 2-MIB, and PMC shows higher removal efficiency of geosmin (46\%) and 2-MIB (37\%) than other chemical coagulant reported in previous studies [32,33]. After the PMC coagulation, the residual geosmin and 2-MIB was found to be about 73.63 and $99.85 \mathrm{ng} / \mathrm{L}$, respectively. However, the average threshold of geosmin and 2-MIB concentrations is approximately $10 \mathrm{ng} / \mathrm{L}$ [34], thus further removal of geosmin and 2-MIB is still needed. Therefore, to enhance the removal efficiency of these compounds a PMC-based coagulation process followed by AOP process was carried out.

\section{5. $U V / \mathrm{H}_{2} \mathrm{O}_{2}$ and $U V / C l_{2}$ for TEO Removal, Lab-Scale}

This study investigated two different $\mathrm{UV}$ based AOPs, i.e., $\mathrm{UV} / \mathrm{H}_{2} \mathrm{O}_{2}$ and $\mathrm{UV} / \mathrm{Cl}_{2}$ processes, to enhance the geosmin and 2-MIB removal efficiencies after the PMC-based coagulation process. Both of the processes are known to generate hydroxyl radical $(\bullet \mathrm{OH})$, which reacts non-selectively with a wide range of organic and inorganic compounds, by the photolytic decomposition of $\mathrm{H}_{2} \mathrm{O}_{2}, \mathrm{HOCl}$, and $\mathrm{OCl}^{-}[35]$ as following equations:

$$
\begin{aligned}
& \mathrm{H}_{2} \mathrm{O}_{2}+h \mathrm{v} \rightarrow 2 \bullet \mathrm{OH}, \\
& \mathrm{HOCl}+h \mathrm{v} \rightarrow \bullet \mathrm{OH}+\mathrm{Cl} \bullet, \\
& \mathrm{OCl}^{-}+h \mathrm{v} \rightarrow \mathrm{O} \bullet^{-}+\mathrm{Cl} \bullet \text {, } \\
& \mathrm{O}^{-}+\mathrm{H}_{2} \mathrm{O} \rightarrow \bullet \mathrm{OH}+\mathrm{OH}^{-} \text {. }
\end{aligned}
$$

For the case of the $\mathrm{UV} / \mathrm{Cl}_{2}$ process, it is known that there are formation of reactive chlorine species (i.e., $\mathrm{Cl} \bullet, \mathrm{Cl}_{2}{ }^{-} \bullet$, and $\mathrm{ClO} \bullet$ ), but it was reported that $\mathrm{OH} \bullet$ is a primarily radical species to the degradation of taste-and-odor compounds as compared to reactive chlorine species which are formed in the $\mathrm{UV} / \mathrm{Cl}_{2}$ process [36].

Treatment in the presence of algae species using oxidation processes has drawbacks such as undesirable toxins and taste and odor compounds [37,38]; therefore, the AOPs were applied after the coagulation process with the optimum PMC dose, i.e., $20 \mathrm{mg} / \mathrm{L}$. In addition, since AOPs performance is significantly affected by DOC and $\mathrm{UV}_{254}$ level [39], higher performance of AOPs is expected after the coagulation with the PMC-based process.

Figure 7 shows the geosmin and 2-MIB removal with the $\mathrm{UV} / \mathrm{Cl}_{2}$ and $\mathrm{UV} / \mathrm{H}_{2} \mathrm{O}_{2}$ processes. UV doses were varied as around 200 , and $700 \mathrm{~mJ} / \mathrm{cm}^{2}$, and oxidant dose was $5 \mathrm{mg} / \mathrm{L}$. The initial $\mathrm{pH}$ of the test water was approximately 6.9 , but it was increased to 7.4 after the injection of $5 \mathrm{mg} / \mathrm{L}$ of $\mathrm{Cl}_{2}$ because of the basic $\mathrm{pH}$ of sodium hydrochloric acid solution and low buffer system of tested water (alkalinity $=27.5 \mathrm{mg} / \mathrm{L}$ as $\mathrm{CaCO}_{3}$ ). No $\mathrm{pH}$ change was observed after the injection of $\mathrm{H}_{2} \mathrm{O}_{2}$.

In both processes, the removal efficiency of geosmin and 2-MIB increased as UV dose increased. The removal of geosmin and 2-MIB in the processes could be explained by the $\bullet \mathrm{OH}$ formation and reaction with those compounds. It is known that geosmin and 2-MIB are not photo-reactive compounds [12] but highly reactive with $\bullet \mathrm{OH}\left(\mathrm{k}_{\mathrm{OH}}\right.$, geosmin $=7.8 \times 10^{9} \mathrm{M}^{-1} \cdot \mathrm{s}^{-1}$ and $\mathrm{k}_{\mathrm{OH}, 2-\mathrm{MIB}}=5.1 \times 10^{9} \mathrm{M}^{-1} \cdot \mathrm{s}^{-1}$ ) [40].

At the same UV dose of $700 \mathrm{~mJ} / \mathrm{cm}^{2}$, the $\mathrm{UV} / \mathrm{H}_{2} \mathrm{O}_{2}$ process shows higher removal efficiency ( $87.2 \%$ of geosmin and $71.4 \%$ of $2-\mathrm{MIB})$ than $\mathrm{UV} / \mathrm{Cl}_{2}$ process ( $62 \%$ of geosmin and $38 \%$ of $\left.2-\mathrm{MIB}\right)$. This result could be explained by the speciation of free chlorine $\left(\mathrm{HOCl}\right.$ and $\left.\mathrm{OCl}^{-}\right)$with $\mathrm{pKa}$ 7.5. At the condition of $\mathrm{pH}$ higher than $7.5, \mathrm{OCl}^{-}$is the predominant species, and it is known that the $\bullet \mathrm{OH}$ scavenging rate by $\mathrm{OCl}^{-}\left(\mathrm{k}_{\mathrm{OH}, \mathrm{OCl}}=8.80 \times 10^{9} \mathrm{M}^{-1} \cdot \mathrm{s}^{-1}\right)$ is much higher than $\mathrm{H}_{2} \mathrm{O}_{2}\left(\mathrm{k}_{\mathrm{OH}, \mathrm{H} 2 \mathrm{O} 2}=2.7 \times 10^{7} \mathrm{M}^{-1} \cdot \mathrm{s}^{-1}\right)$ and $\mathrm{HOCl}\left(\mathrm{k}_{\mathrm{OH}, \mathrm{HOCl}}=8.46 \times 10^{4} \mathrm{M}^{-1} \cdot \mathrm{s}^{-1}\right.$ [41]; therefore, it is reported that the removal efficiency of geosmin and 2-MIB in the $\mathrm{UV} / \mathrm{H}_{2} \mathrm{O}_{2}$ process could be higher at $\mathrm{pH}$ above 7 than the $\mathrm{UV} / \mathrm{Cl}_{2}$ process [36].

Between the two compounds, geosmin removal efficiency was higher than 2-MIB in both processes. This is because geosmin has higher reactivity with $\bullet \mathrm{OH}$ than 2-MIB. 


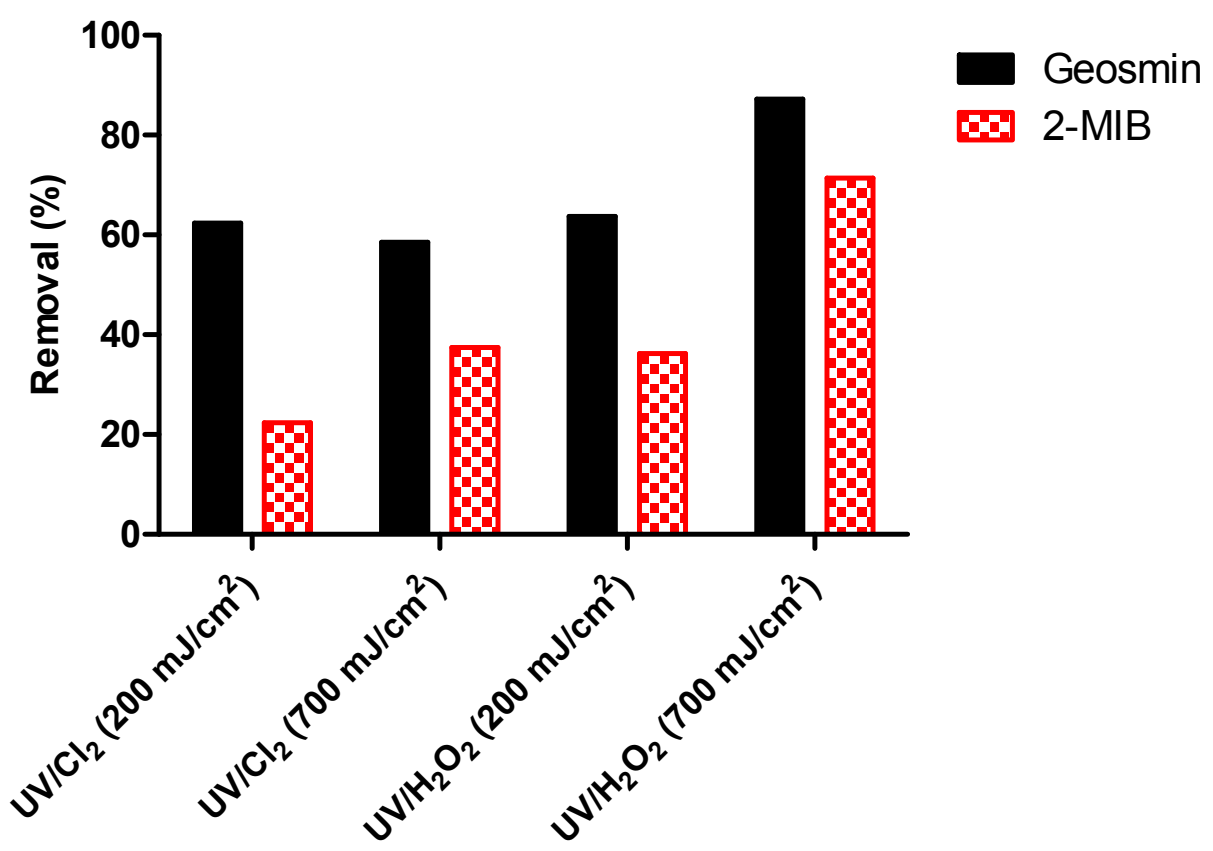

Figure 7. Trends in geosmin and 2-MIB removal by the $\mathrm{UV} / \mathrm{Cl}_{2}$, and $\mathrm{UV} / \mathrm{H}_{2} \mathrm{O}_{2}$ processes at the lab-scale (initial geosmin concentration: $134.58 \mathrm{ng} / \mathrm{L}$; initial 2-MIB concentration: $159.02 \mathrm{ng} / \mathrm{L}$; UV dose: 0 , 200, and $700 \mathrm{~mJ} / \mathrm{cm}^{2} ; \mathrm{Cl}_{2}$ dose: $5 \mathrm{mg} / \mathrm{L} ; \mathrm{H}_{2} \mathrm{O}_{2}$ dose: $5 \mathrm{mg} / \mathrm{L}$; initial $\mathrm{pH}: 6.9$ ).

\subsection{Coagulation Test in Pilot Scale}

The pilot-scale PMC-based coagulation experiments were conducted with varying doses of PMC (from 10 to $40 \mathrm{mg} / \mathrm{L}$ ) at $109 \mathrm{~m}^{3} / \mathrm{h}$ flow rate. The algae removal performance of the PMC-based coagulant in the pilot-scale tests is shown in Figure 8. The chlorophyll-a removal efficiencies in the pilot-scale tests were found to be from $78.0-96.0 \%, 80.0-98.7 \%, 90.0-99.6 \%$ and $78-95 \%$ (depending on the period of experiment) at PMC-based coagulant doses of 10, 20, 30, and $40 \mathrm{mg} / \mathrm{L}$, respectively (Figure 8). The removal trends of algae and turbidity were similar. The coagulation process with PMC showed good algae removal efficiencies in the pilot-scale tests.

Figure 9 shows the turbidity and $\mathrm{UV}_{254}$ data before and after PMC coagulation process. The raw water turbidity was varied from 1.6 to 11.8 turbidity (NTU). The turbidity removal efficiencies in the pilot-scale tests were found to be from $33.3-41.4 \%, 41.2-77.4 \%, 48.3-84.0 \%$ and $36.7-78.9 \%$ (depending on the period of experiment) at PMC doses of 10, 20, 30, and $40 \mathrm{mg} / \mathrm{L}$, respectively (Figure 9a). Additionally, the average $\mathrm{UV}_{254}$ removal efficiencies in the pilot-scale tests were approximately $35.6-45.7 \%, 41.4-48.9 \%, 36.7-62.4 \%$, and $42.6-57.6 \%$ (depending on the period of experiment) at PMC doses of 10, 20, 30, and $40 \mathrm{mg} / \mathrm{L}$, respectively (Figure 9b). Moreover, the turbidity removal efficiency of the coagulation process increased as the level of turbidity increased. Even though the turbidity removal efficiency was not as high as the lab-scale test, the turbidity level after treatment was low.

The optimum PMC-based coagulant dose was $20 \mathrm{mg} / \mathrm{L}$ for all levels of turbidity in the lab-scale tests. However, the optimum dose for the pilot-scale tests was varied depending on the level of turbidity from $20-30 \mathrm{mg} / \mathrm{L}$, which is $10 \mathrm{mg} / \mathrm{L}$ higher dose than the lab-scale. The maximum levels of turbidity of the test water were 4.6 and 11.8 NTU for the lab-scale and pilot-scale tests, respectively. Further increase in PMC dose $(40 \mathrm{mg} / \mathrm{L})$ decreases the turbidity removal efficiency. This indicates the occurrence of charge reversal which causes the particles in the test water to be positively charged during the coagulation process and therefore the particles start to restabilize at high PMC coagulant doses. Similarly, chemical coagulants, such as polyaluminium chloride have been reported to decrease turbidity removal efficiencies at doses above the respective optimum doses [42-44]. The turbidity 
removal was higher in the lab-scale than the pilot-scale test at the optimum dose of PMC (20-30 mg/L). For instance, in case of the turbidity of 4.7 NTU, the removal efficiency in the lab scale was $93.4 \%$ but the obtained value from the pilot-tests was approximately $70.2 \%$. Even though the turbidity removal efficiency was not as high as the lab-scale test, the turbidity level after treatment was low. The optimum PMC doses difference for the turbidity removal efficiency in the lab-scale test and pilot-scale tests could be due to the differences in the water matrices. Therefore, a PMC dose of $30 \mathrm{mg} / \mathrm{L}$ was used for the removal of both $\mathrm{T} \& \mathrm{O}$ compounds in the pilot-scale tests.

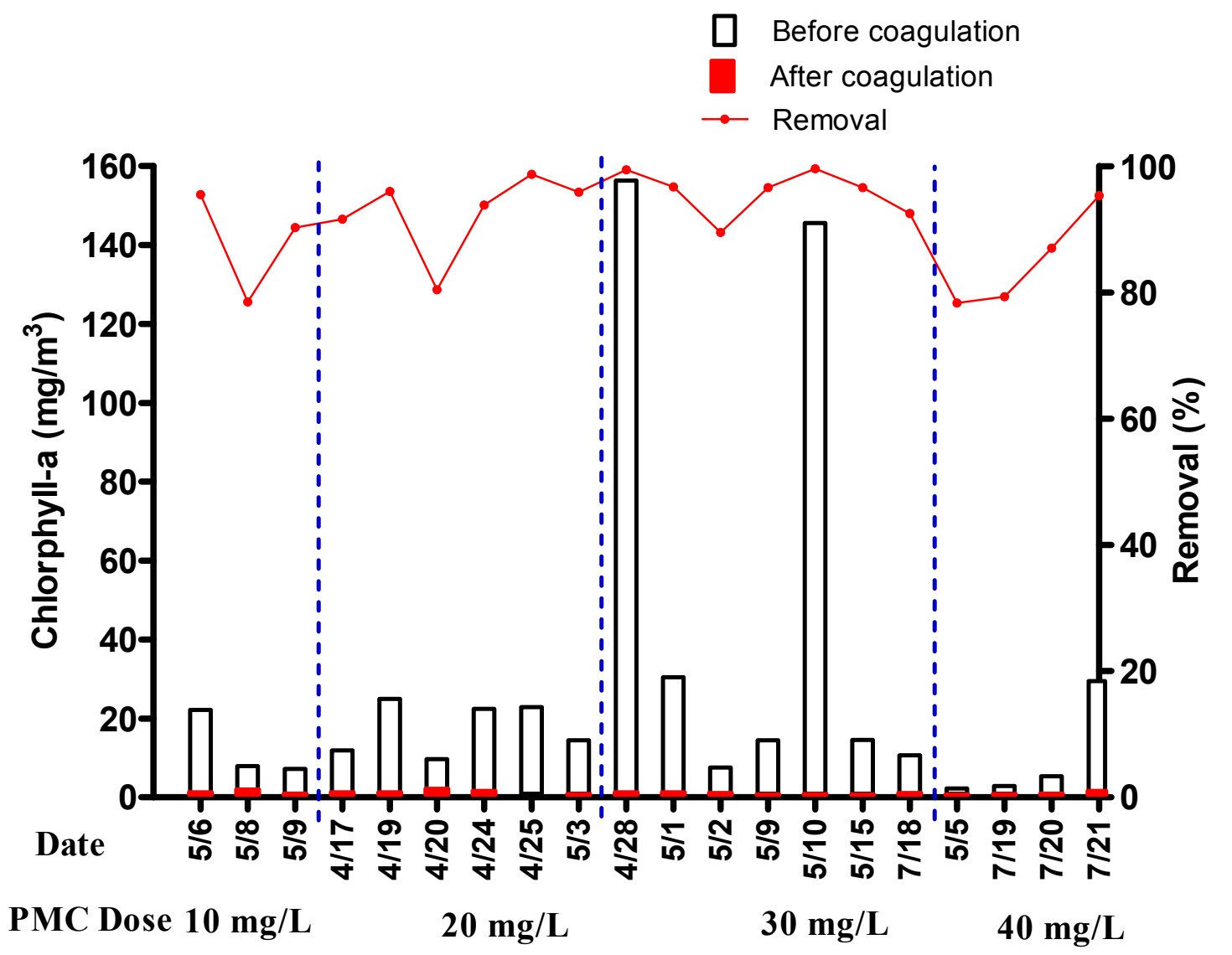

Figure 8. Concentrations of chlorophyll-a before and after coagulation using the PMC-based coagulant in the pilot-scale tests (PMC dose: 10, 20, 30, and $40 \mathrm{mg} / \mathrm{L}$ ).

\section{7. $\mathrm{UV} / \mathrm{H}_{2} \mathrm{O}_{2}$ and $\mathrm{UV} / \mathrm{Cl}_{2}$ Process in Pilot Scale}

The oxidation of geosmin and 2-MIB in the $\mathrm{UV} / \mathrm{H}_{2} \mathrm{O}_{2}$ and $\mathrm{UV} / \mathrm{Cl}_{2}$ processes was evaluated after the PMC coagulation process with PMC dose of $30 \mathrm{mg} / \mathrm{L}$. For the UV based AOPs, background water characteristics are significantly important for removal efficiency of target compounds. As mentioned in Section 3.6, after coagulation process using PMC, the water quality was notably increased as follows: DOC $(1.3 \rightarrow 0.8 \mathrm{mg} / \mathrm{L}), \mathrm{UV}_{254}\left(0.0695 \rightarrow 0.0272 \mathrm{~cm}^{-1}\right)$, and turbidity $(31.1 \rightarrow 15.6 \mathrm{NTU})$. To predict the performance of UV-based AOPs, the scavenging factor could be an indicator for $\bullet \mathrm{OH}$ water background demand $\left(\mathrm{s}^{-1}\right)$. The scavenging factors were measured before and after the PMC treatment (Figure S1). As expected, the scavenging factor was notably decreased after PMC treatment $\left(64998 \rightarrow 28516 \mathrm{~s}^{-1}\right)$. The UV transmittance was increased $(85 \rightarrow 4 \%)$. This could be explained by the decreased DOC and $\mathrm{UV}_{254}$ after the PMC process because DOMs are the main water constituents considered in the estimation of $\bullet \mathrm{OH}$ scavenging rates in natural waters [16]. Moreover, removal of turbidity could increase the performance of UV based AOPs because turbidity causing particles can 
act as a 'screen' that reduces the amount of light reaching $\mathrm{H}_{2} \mathrm{O}_{2}$ or $\mathrm{Cl}_{2}$; therefore, those oxidants do not receive sufficient $\mathrm{UV}$ photons for $\bullet \mathrm{OH}$ production [12].

(a)

Before

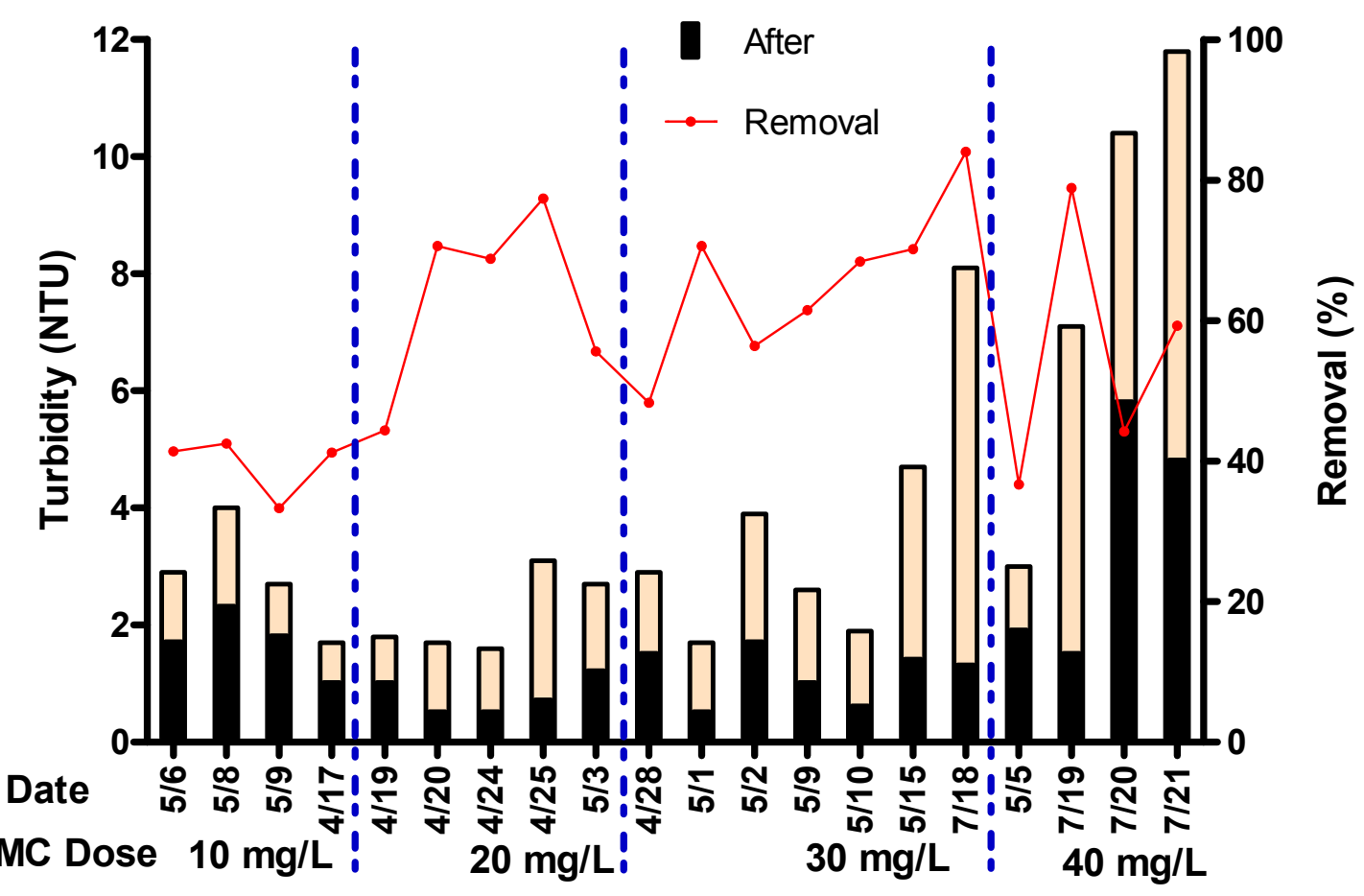

(b)

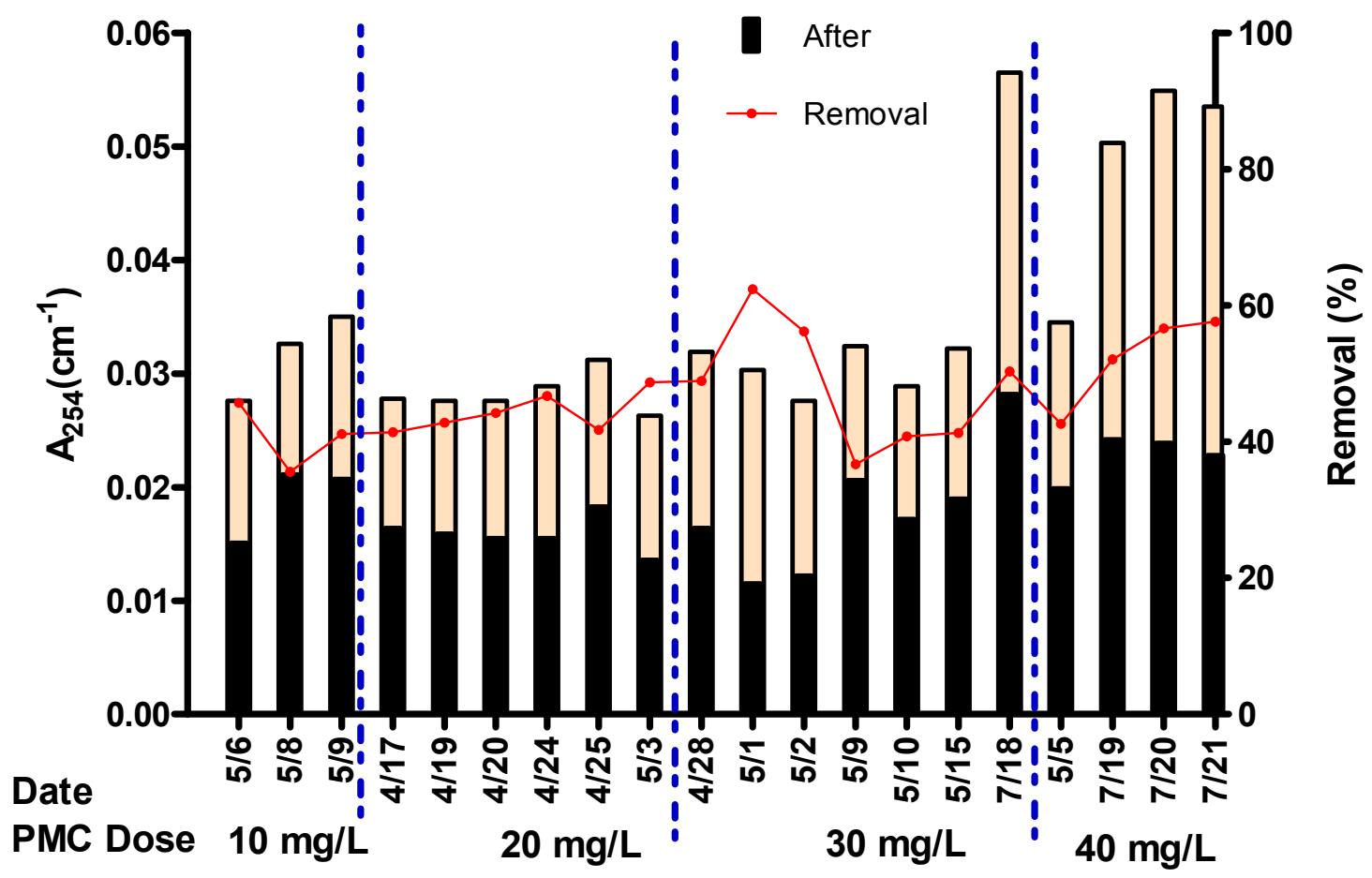

Figure 9. Removal of turbidity (a) and $\mathrm{UV}_{254}$ (b) with varying doses of the PMC-based coagulant in the pilot-scale tests $(10,20,30$, and $40 \mathrm{mg} / \mathrm{L})$. 
Since there was no geosmin and 2-MIB issue during pilot-tests, we could not verify the removal of those compounds in the PMC coagulation process. Instead, we split the PMC treated water from the main line flow $\left(109 \mathrm{~m}^{3} / \mathrm{h}\right)$ into the smaller flow rate $\left(1.8 \mathrm{~m}^{3} / \mathrm{h}\right)$ for the spiking test of taste and odor compounds in $\mathrm{UV} / \mathrm{H}_{2} \mathrm{O}_{2}$ and $\mathrm{UV} / \mathrm{Cl}_{2}$ for AOPs. Figure 10 shows the degradation of geosmin and 2-MIB by $\mathrm{UV}$ alone, $\mathrm{UV} / \mathrm{H}_{2} \mathrm{O}_{2}$, and $\mathrm{UV} / \mathrm{Cl}_{2}$ processes with varying concentrations of $\mathrm{H}_{2} \mathrm{O}_{2}$ and $\mathrm{Cl}_{2}(0,2,5$, and $10 \mathrm{mg} / \mathrm{L})$. The change in geosmin and 2-MIB concentration by UV direct photolysis was not significant, but it was significantly decreased by injection of $\mathrm{H}_{2} \mathrm{O}_{2}$ and $\mathrm{Cl}_{2}$. Interestingly, the removal efficiency of both of the compounds in the $\mathrm{UV} / \mathrm{H}_{2} \mathrm{O}_{2}$ process increased with increasing $\mathrm{H}_{2} \mathrm{O}_{2}$ dose, but the UV/Cl $/ \mathrm{Cl}_{2}$ process had a lower removal at a higher $\mathrm{Cl}_{2}$ dose. One plausible reason is the $\mathrm{pH}$ change by the injection of $\mathrm{Cl}_{2}$. Similar to the lab test, the $\mathrm{pH}$ values were constant at 6.7 in the $\mathrm{UV} / \mathrm{H}_{2} \mathrm{O}_{2}$ process; however the $\mathrm{pH}$ levels of the test water after the injection of 2, 5, and $10 \mathrm{mg} / \mathrm{L}$ chlorine were 6.9, 7.5, and 7.9, respectively. As mentioned in previous Section 3.5, the performance of the $\mathrm{UV} / \mathrm{Cl}_{2}$ process is highly dependent on $\mathrm{pH}$ and could be decreased at the higher $\mathrm{pH}$ than $\mathrm{pH} 7$ because of higher scavenging effect by $\mathrm{OCl}^{-}$than by $\mathrm{HOCl}$. From this result, the PMC/UV $/ \mathrm{H}_{2} \mathrm{O}_{2}$ process can suggested as effective treatment process for geosmin and 2-MIB.

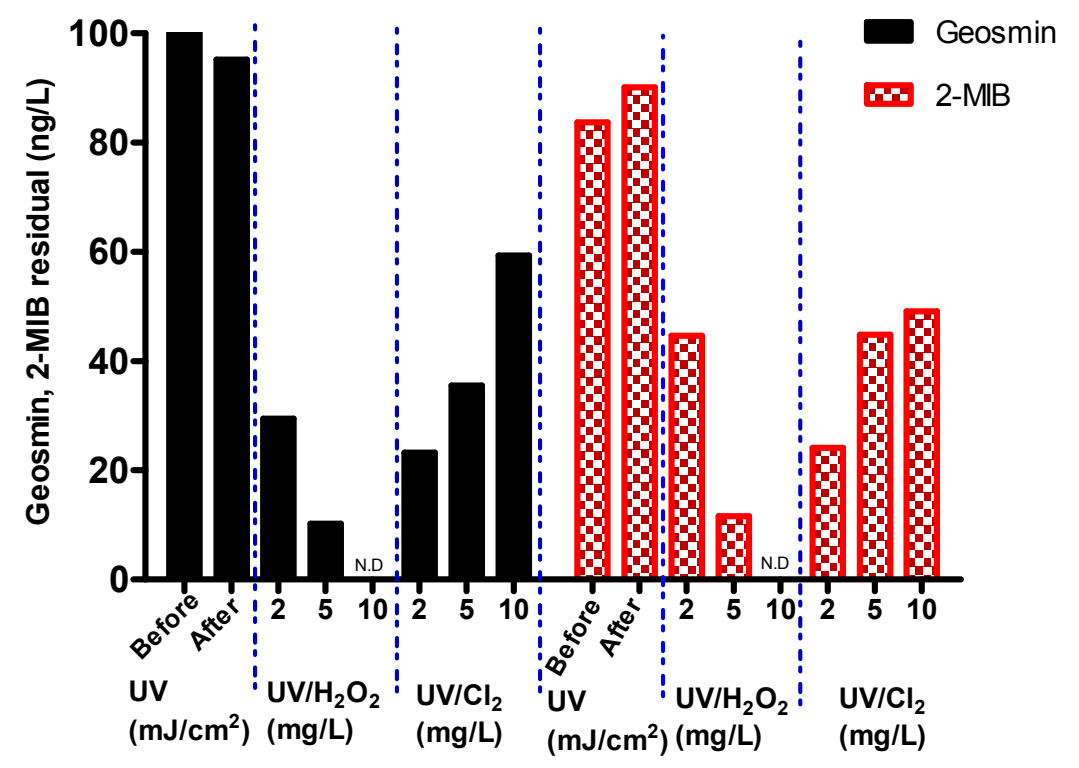

Figure 10. Degradation of geosmin and 2-MIB by $\mathrm{UV}, \mathrm{UV} / \mathrm{H}_{2} \mathrm{O}_{2}$, and $\mathrm{UV} / \mathrm{Cl}_{2}$ processes in the pilot-scale test (PMC dose: $20 \mathrm{mg} / \mathrm{L}$; UV dose: $871.8 \mathrm{~mJ} / \mathrm{cm}^{2} ; \mathrm{Cl}_{2}$ dose: 2, 5, and $10 \mathrm{mg} / \mathrm{L}_{2} \mathrm{H}_{2} \mathrm{O}_{2}$ dose: $2,5$, and $10 \mathrm{mg} / \mathrm{L})$.

The concentrations of geosmin and 2-MIB in the surface water were successfully reduced using the $\mathrm{UV} / \mathrm{H}_{2} \mathrm{O}_{2}$ process. Lower than average taste and odor threshold of geosmin and 2-MIB $(10 \mathrm{ng} / \mathrm{L})$ was achieved in the $\mathrm{UV} / \mathrm{H}_{2} \mathrm{O}_{2}$ process with $>5 \mathrm{mg} / \mathrm{L} \mathrm{H}_{2} \mathrm{O}_{2}$.

These results emphasize that UV-based AOPs are applicable at the water intake stage when algae and turbidity are successfully removed using PMC. However, it is true that the performance of UV-based AOPs will be increased if the processes are installed after filtration process of the main water treatment processes. This is because the UV-based AOPs are highly dependent on the UV transmittance.

\section{Conclusions}

In this study, the coagulation efficiency of the PMC-based coagulant and the algae, geosmin, and 2-MIB removal efficiencies of the combined application of this coagulant with UV-based AOPs were investigated. The coagulation efficiency of the PMC-based coagulant was high in both the lab-scale and pilot-scale tests. In the lab-scale test, the removal efficiency of PMC showed $98 \%$ 
of the high initial algae concentration $\left(97.1 \mathrm{mg} / \mathrm{m}^{3}\right)$ and more than $94 \%$ of the turbidity removal. The geosmin and 2-MIB removal by the PMC coagulation process was found to be $45 \%$ and $37 \%$, respectively. However, the level of residual $\mathrm{T} \& \mathrm{O}$ compound was above the threshold. In the pilot-scale test, coagulation process using PMC showed $64 \%$ and $96 \%$ of the average turbidity and chlorophyll-a removal efficiencies, respectively. For the PMC-based coagulation combined with $\mathrm{UV} / \mathrm{H}_{2} \mathrm{O}_{2}$ and $\mathrm{UV} / \mathrm{Cl}_{2}$ processes, the change in geosmin and 2-MIB concentration by $\mathrm{UV}$ direct photolysis was not significant, but it was significantly decreased after the injection of $\mathrm{H}_{2} \mathrm{O}_{2}$. Complete degradation of geosmin and 2-MIB was achieved when the $\mathrm{H}_{2} \mathrm{O}_{2}$ (oxidant) dose was increased to $10 \mathrm{mg} / \mathrm{L}$. The UV $/ \mathrm{H}_{2} \mathrm{O}_{2}$ process was superior to the $\mathrm{UV} / \mathrm{Cl}_{2}$ process in both the lab-scale and pilot-scale experiments. It was also observed that water quality parameters such as turbidity reduced the efficiency of the oxidation process. Thus, it was concluded that combining the PMC-based coagulant with $\mathrm{UV} / \mathrm{H}_{2} \mathrm{O}_{2}$ processes is an efficient coagulation process for the removal of $\mathrm{T} \& \mathrm{O}$ compounds and the producers of such compounds (algae). Further research is needed to optimize the combination of AOP with different coagulation options for different water matrices. A cost-comparison analysis with other coagulants is also required.

Supplementary Materials: The following are available online at http:/ /www.mdpi.com/2076-3417/8/9/1502/s1, Figure S1: Determination of scavenging factor for the water sample before and after PMC treatment used in collimated beam work: $R_{O H, U V}$ variation with the initial $\mathrm{H}_{2} \mathrm{O}_{2}$ concentration.

Author Contributions: Y.W.A. (data curation, writing, original draft); H.K. (data curation, methodology, review and editing); M.K. (formal analysis, writing, review and editing); D.L. (data curation, review and editing); K.K. (data curation, review and editing); Y.J. (writing, review and editing); Y.A. (review and editing); J.W.K. (supervision, Project administration, writing, review and editing).

Funding: This research was funded by the Korea Ministry of Environment (MOE) as "A real scale project on algae monitoring and removal-utilization technology" (2014001800001).

Conflicts of Interest: The authors declare no conflicts of interest.

\section{References}

1. Cook, D.; Newcombe, G. Can we predict the removal of MIB and geosmin with PAC by using water quality parameters? Water Sci. Technol. Water Supply 2004, 4, 221-226. [CrossRef]

2. Jiang, J.Q.; Kim, C. Comparison of algal removal by coagulation with clays and Al-based coagulants. Sep. Sci. Technol. 2008, 43, 1677-1686. [CrossRef]

3. Pirbazari, M.; Ravindran, V.; Badriyha, B.N.; Craig, S.; McGuire, M.J. GAC adsorber design protocol for the removal of off-flavors. Water Res. 1993, 27, 1153-1166. [CrossRef]

4. Kang, S.J.; Lim, S.I.; Lee, B.H. The removal of red tide organisms by using microscreen and ozone. J. Korea Technol. Soc. Water Waste Water Treat. 2001, 9, 11-17.

5. Zamyadi, A.; Henderson, R.; Stuetz, R.; Hofmann, R.; Ho, L.; Newcombe, G. Fate of geosmin and 2-methylisoborneol in full-scale water treatment plants. Water Res. 2015, 83, 171-183. [CrossRef] [PubMed]

6. Knappe, D.R.; Belk, R.C.; Briley, D.S.; Gandy, S.R.; Rastogi, N.; Rike, A.H.; Glasgow, H.; Hannon, E.; Frazier, W.D.; Kohl, P.; et al. Algae Detection and Removal Strategies for Drinking Water Treatment Plants; AWWA Research Foundation: Denver, CO, USA, 2004.

7. Zhang, G.; Wang, B.; Zhang, P.; Wang, L.; Wang, H. Removal of algae by sonication-coagulation. J. Environ. Sci. Health Part A 2006, 41, 1379-1390. [CrossRef] [PubMed]

8. Betatache, H.; Aouabed, A.; Drouiche, N.; Lounici, H. Conditioning of sewage sludge by prickly pear cactus (Opuntia ficus Indica) juice. Ecol. Eng. 2014, 70, 465-469. [CrossRef]

9. Jodi, M.; Birnin-Yauri, U.; Yahaya, Y.; Sokoto, M. The use of some plants in water purification. Glob. Adv. Res. J. Chem. Mater. Sci. 2012, 4, 071-075.

10. Kim, B.H.; Lee, J.H.; Kim, K.H.; Yu, Y.H.; Hwang, S.J. Algal growth inhibition activity of domestic plants and minerals using simple extraction method. Korean J. Ecol. Environ. 2010, 43, 221-231.

11. Kim, B.H.; Lee, J.H.; Park, C.H.; Kwon, D.Y.; Park, H.J.; Mun, B.C.; Mun, B.J; Choi, I.C.; Kim, N.Y.; Min, H.N. Effects of plant-mineral composites (PMC) on the water quality, plankton community and microcystin-LR in eutrophic waters. Korean J. Ecol. Environ. 2011, 44, 347-357. 
12. Rosenfeldt, E.J.; Melcher, B.; Linden, K.G. UV and UV/H2 O2 treatment of methylisoborneol (MIB) and geosmin in water. J. Water Supply Res. Technol.-AQUA 2005, 54, 423-434. [CrossRef]

13. Comninellis, C.; Kapalka, A.; Malato, S.; Parsons, S.A.; Poulios, I.; Mantzavinos, D. Advanced oxidation processes for water treatment: Advances and trends for R\&D. J. Chem. Technol. Biotechnol. 2008, 83, 769-776.

14. Das, P.; Lei, W.; Aziz, S.S.; Obbard, J.P. Enhanced algae growth in both phototrophic and mixotrophic culture under blue light. Bioresour. Technol. 2011, 102, 3883-3887. [CrossRef] [PubMed]

15. Bolton, J.R.; Linden, K.G. Linden, Standardization of methods for fluence (UV dose) determination in bench-scale UV experiments. J. Environ. Eng. 2003, 129, 209-215. [CrossRef]

16. Kwon, M.; Kim, S.; Yoon, Y.; Jung, Y.; Hwang, T.M.; Kang, J.W. Prediction of the removal efficiency of pharmaceuticals by a rapid spectrophotometric method using Rhodamine B in the $\mathrm{UV} / \mathrm{H}_{2} \mathrm{O}_{2}$ process. Chem. Eng. J. 2014, 236, 438-447. [CrossRef]

17. Kwon, M.; Kim, S.; Yoon, Y.; Jung, Y.; Hwang, T.M.; Lee, J.; Kang, J.W. Comparative evaluation of ibuprofen removal by UV/H2 O2 and UV/S2 O82-Processes for wastewater treatment. Chem. Eng. J. 2015, 269, 379-390. [CrossRef]

18. Liu, S.; Tang, L.; Wu, M.; Fu, H.; Xu, J.; Chen, W.; Ma, F. Parameters influencing elimination of geosmin and 2-methylisoborneol by $\mathrm{K}_{2}$ FeO4. Sep. Purif. Technol. 2017, 182, 128-133. [CrossRef]

19. Kwon, M.; Yoon, Y.; Kim, S.; Jung, Y.; Hwang, T.M.; Kang, J.W. Removal of sulfamethoxazole, ibuprofen and nitrobenzene by UV and UV/chlorine processes: A comparative evaluation of $275 \mathrm{~nm}$ LED-UV and $254 \mathrm{~nm}$ LP-UV. Sci. Total Environ. 2018, 637, 1351-1357. [CrossRef] [PubMed]

20. Lee, D.; Kwon, M.; Ahn, Y.; Jung, Y.; Nam, S.N.; Choi, I.H.; Kang, J.W. Characteristics of intracellular algogenic organic matter and its reactivity with hydroxyl radicals. Water Res. 2018, 144, 13-25. [CrossRef] [PubMed]

21. Liu, W.; Andrews, S.A.; Stefan, M.I.; Bolton, J.R. Optimal methods for quenching $\mathrm{H}_{2} \mathrm{O}_{2}$ residuals prior to UFC testing. Water Res. 2003, 37, 3697-3703. [CrossRef]

22. Wu, X.; Ge, X.; Wang, D.; Tang, H. Distinct coagulation mechanism and model between alum and high Al 13-PACl. Coll. Surf. A Physicochem. Eng. Asp. 2007, 305, 89-96. [CrossRef]

23. Edzwald, J.K.; Kaminski, G.S. A practical method for water plants to select coagulant dosing. J. N. Engl. Water Works Assoc. 2009, 123, 15-31.

24. Matilainen, A.; Lindqvist, N.; Tuhkanen, T. Comparison of the effiency of aluminium and ferric sulphate in the removal of natural organic matter during drinking water treatment process. Environ. Technol. 2005, 26, 867-876. [CrossRef] [PubMed]

25. Ghernaout, D.; Ghernaout, B.; Kellil, A. Natural organic matter removal and enhanced coagulation as a link between coagulation and electrocoagulation. Desalin. Water Treat. 2009, 2, 203-222. [CrossRef]

26. Vilgé-Ritter, A.; Masion, A.; Boulangé, T.; Rybacki, D.; Bottero, J.Y. Removal of natural organic matter by coagulation-flocculation: A pyrolysis-GC-MS study. Environ. Sci. Technol. 1999, 33, 3027-3032. [CrossRef]

27. Matilainen, A.; Sillanpää, M. Removal of natural organic matter from drinking water by advanced oxidation processes. Chemosphere 2010, 80, 351-365. [CrossRef] [PubMed]

28. Ndabigengesere, A.; Narasiah, K.S.; Talbot, B.G. Active agents and mechanism of coagulation of turbid waters using Moringa oleifera. Water Res. 1995, 29, 703-710. [CrossRef]

29. Ives, K.J. Electrokinetic phenomena of planktonic algae. Proc. Soc. Water Treat. Exam. 1956, 5, 41-58.

30. Ye, C.; Wang, D.; Shi, B.; Yu, J.; Qu, J.; Edwards, M.; Tang, H. Alkalinity effect of coagulation with polyaluminum chlorides: Role of electrostatic patch. Coll. Surf. A Physicochem. Eng. Asp. 2007, 294, 163-173. [CrossRef]

31. Yan, M.; Wang, D.; Yu, J.; Ni, J.; Edwards, M.; Qu, J. Enhanced coagulation with polyaluminum chlorides: Role of pH/alkalinity and speciation. Chemosphere 2008, 71, 1665-1673. [CrossRef] [PubMed]

32. Bruce, D.; Westerhoff, P.; Brawley-Chesworth, A. Removal of 2-methylisoborneol and geosmin in surface water treatment plants in Arizona. J. Water Supply Res. Technol.-AQUA 2002, 51, 183-198. [CrossRef]

33. Luo, Y.; Guo, W.; Ngo, H.H.; Nghiem, L.D.; Hai, F.I.; Zhang, J.; Liang, S.; Wang, X.C. A review on the occurrence of micropollutants in the aquatic environment and their fate and removal during wastewater treatment. Sci. Total Environ. 2014, 473, 619-641. [CrossRef] [PubMed]

34. Suffet, I.M.; Khiari, D.; Bruchet, A. The drinking water taste and odor wheel for the millennium: Beyond geosmin and 2-methylisoborneo. Water Sci. Technol. 1999, 40, 1-13. [CrossRef] 
35. Kim, T.K.; Moon, B.R.; Kim, T.; Kim, M.K.; Zoh, K.D. Degradation mechanisms of geosmin and 2-MIB during UV photolysis and UV/chlorine reactions. Chemosphere 2016, 162, 157-164. [CrossRef] [PubMed]

36. Fang, J.; Liu, J.; Shang, C.; Fan, C. Degradation Investigation of Selected Taste and Odor Compounds by a UV/Chlorine Advanced Oxidation Process. Int. J. Environ. Res. Public Health 2018, 15, 284. [CrossRef] [PubMed]

37. Hall, T.; Hart, J.; Croll, B.; Gregory, R. Laboratory-scale investigations of algal toxin removal by water treatment. Water Environ. J. 2000, 14, 143-149. [CrossRef]

38. Henderson, R.; Parsons, S.A.; Jefferson, B. The impact of algal properties and pre-oxidation on solid-liquid separation of algae. Water Res. 2008, 42, 1827-1845. [CrossRef] [PubMed]

39. Rosenfeldt, E.J.; Linden, K.G. The R OH, UV concept to characterize and the model UV $/ \mathrm{H}_{2} \mathrm{O}_{2}$ process in natural waters. Environ.Sci. Technol. 2007, 41, 2548-2553. [CrossRef]

40. Peter, A.; Von Gunten, U. Oxidation kinetics of selected taste and odor compounds during ozonation of drinking water. Environ. Sci. Technol. 2007, 41, 626-631. [CrossRef] [PubMed]

41. Watts, M.J.; Linden, K.G. Chlorine photolysis and subsequent $\mathrm{OH}$ radical production during UV treatment of chlorinated water. Water Res. 2007, 41, 2871-2878. [CrossRef] [PubMed]

42. Graham, N.; Gang, F.; Fowler, G.; Watts, M. Characterisation and coagulation performance of a tannin-based cationic polymer: A preliminary assessment. Coll. Surf. A Physicochem. Eng. Asp. 2008, 327, 9-16. [CrossRef]

43. Yan, M.; Wang, D.; You, S.; Qu, J.; Tang, H. Enhanced coagulation in a typical North-China water treatment plant. Water Res. 2006, 40, 3621-3627. [CrossRef] [PubMed]

44. Choy, S.Y.; Prasad, K.N.; Wu, T.Y.; Raghunandan, M.E.; Ramanan, R.N. Performance of conventional starches as natural coagulants for turbidity removal. Ecol. Eng. 2016, 94, 352-364. [CrossRef]

(C) 2018 by the authors. Licensee MDPI, Basel, Switzerland. This article is an open access article distributed under the terms and conditions of the Creative Commons Attribution (CC BY) license (http:/ / creativecommons.org/licenses/by/4.0/). 